\title{
Sirenomelia in Dicephalic parapagus twins discordant for anencephaly and spina bifida.
}

\author{
Tripti Shrestha, Gehanath Baral, Nesuma Sedhain \\ Paropakar Maternity \& Women's Hospital, Kathmandu, Nepal \\ Received: December 31, 2019 \\ Accepted: March 15, 2020
}

\begin{abstract}
An extremely rare case of sirenomelia in dicephalic parapagus twins discordant for anencephaly and spina bifida that was diagnosed after birth is presented. High incidence of congenital anomalies both with sirenomelia and parapagus twins independently make the prognosis much worse, with additional neural tube defect rendering it almost incompatible with life. Termination of pregnancy is advised when diagnosed in utero.
\end{abstract}

Key words: anencephaly, dicephalic parapagus, spina bifida, sirenomelia

Citation : Shrestha T, Baral G, Sedhain N. Sirenomelia in Dicephalic parapagus twins discordant for anencephaly and spina bifida. Nep J Obstet Gynecol. 2020;15(30):81-83. DOI: 10.3126/njog.v15i1.29349

\section{INTRODUCTION:}

Conjoined twins are a rare occurrence with incidence of 1 in 50,000 to $100,000 . .^{1-7}$ The incidence of live born conjoined twins is around 1 in 200,000 live births. ${ }^{4,7}$ Dicephalic parapagus type is even rare accounting for $0.5 \%$ of all conjoined twins. ${ }^{6}$ Conjoined twins are associated with various congenital abnormalities that may be incompatible with life. ${ }^{4,5}$ Sirenomelia is very rare and fatal congenital anomaly characterized by varying degrees of lower limb fusion associated with other several anomalies. ${ }^{8,9}$

The incidence of sirenomelia is approximately 1 per 100,000 births with a male female ratio of $2.7: 1$ and a greater preponderance in one of two monozygotic twins. ${ }^{9}$ Association of sirenomelia with conjoined twins is extremely rare, with only one case report in the literature. ${ }^{10}$ Hence, we report an extremely rare presentation of sirenomelia in Dicephalic dibrachius parapagus conjoined twins discordant for anencephaly and spina bifida, diagnosed after birth.

\section{CORRESPONDENCE}

Dr Tripti Shrestha

Department of Obstetrics and Gynecology, Paropakar Maternity \& Women's Hospital, Kathmandu, Nepal

Email: drtripti.shrestha22@gmail.com; Mobile: +9779851229042

\section{CASE}

A 26 years old $\mathrm{G}_{6} \mathrm{P}_{2+3}$ visited Paropakar Maternity and Women's hospital at term pregnancy in labour. She had no any antenatal checkups and was unsure of her last menstrual period. She was normotensive and non-diabetic. There was no history of intake of alcohol, tobacco or any teratogenic medicine. She had no known history of genetic, congenital malformations or twinning in the family. The couple was consanguineous. Delivery occurred via emergency caesarean section for oligohydroamnios with non-reassuring CTG.

Examination revealed conjoined twins with two heads discordant for anencephaly, single torso with two upper limbs and spina bifida in anencephalic twin, fused single lower limb without external genitalia and anal opening [Figure-1 and 2]. Anencephalic twin was still born and the other twin died at one hour of life. Parents refused any resuscitation effort. Parents also denied any further investigation including the autopsy of the twins. 


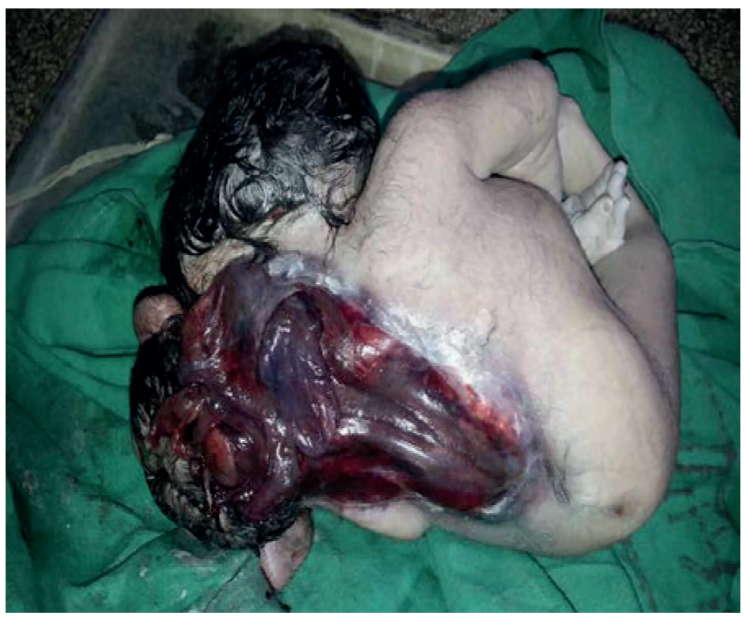

Figure-1: Dorsolateral view of conjoined twins discordant for anencephaly and spina bifida

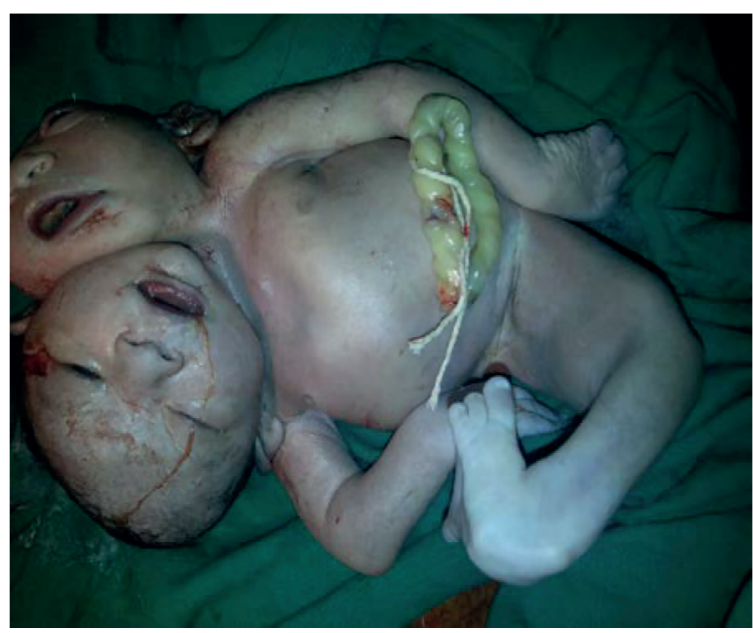

Figure-2: Conjoined twins with two heads fused at thorax and abdomen with two upper limbs, fused lower limb and absent external genitalia.

\section{COMMENTS}

Conjoined twins are genetically identical, monozygotic, monoamniotic and monochorionic twins with fused body part/s, separable or inseparable, which may either due to incomplete division of embryo or due to secondary union of embryonic disc. ${ }^{3,5}$ It is a rare random occurrence not related to hereditary, maternal age and parity consisting of $1 \%$ of monochorionic twins. ${ }^{5,7}$

Dicephalic parapagus is an extremely rare variant of conjoined twins thought to arise from two separate notocords on one embryonic disc situated in close proximation caudally with varying degree of separation rostrally.,6 Their body axes lie side by side with two heads, single trunk with two vertebral columns and two spinal cords, two arms and two legs. Twins are most commonly joined at the chest having separate respiratory and upper gastrointestinal tract but shared genitourinary tract and lower gastrointestinal system, including liver. ${ }^{7,11}$

Various congenital anomalies like complex anomalies of heart, neural tube defects particularly anencephaly, cystic hygroma, orofacial defects (cleft lip/palate), and imperforate anus have been reported in conjoined twins. ${ }^{4,6,7,11}$

Dicephalus parapagus conjoined twin discordant for anencephaly has been reported but is rare. ${ }^{3,12}$ Congenital anomalies are often discordant in conjoined twins, usually involving twin on the right despite being genetically identical to each other unlike our case in which it was present on the left. The relationship between conjoined twinning and anencephaly is unclear. ${ }^{12}$

Sirenomelia, also known as mermaid syndrome, is a very rare and fatal congenital anomaly characterized by varying degrees of lower limb fusion associated with other several anomalies such as imperforate anus, agenesis of kidneys and urinary tract, internal organ agenesis, anomalies of lumbar spine and sacral spine, absent external genitalia. ${ }^{8,9}$

The cause of sirenomelia is not well understood. Retinoic acid, maternal diabetes and heavy metals have been implicated as environmental risk factors for caudal malfomations. The vascular steal hypothesis and the defective blastogenesis hypothesis are the two widely popularized hypotheses in explaining the causal mechanism of sirenomelia. ${ }^{8,9}$

High independent association of congenital anomalies in conjoined twins and sirenomelia poses significant risk for its occurrence in conjoined twins with sirenomelia further worsening its prognosis. There was at least one case report of sirenomelia in thoracopagus conjoined twins found in literature. ${ }^{10}$ Presence of sirenomelia in dicephalic parapagus twins discordant for anencephaly and spina bifida makes it extremely rare finding.

Antenatal diagnosis of conjoined twins is possible with transvaginal ultrasound as early as $8^{\text {th }}$ week of gestation. ${ }^{6}$ 3D ultrasound may be helpful in delineating the complex fetal anomaly of conjoined twins than 2D ultrasound. ${ }^{1,12}$ 
First trimester and early second trimester is most preferrable and accurate time for detection of sirenomelia by ultrasound; oligohydroamnios, bilateral renal agenesis, malformed lower limbs and a single umbilical artery being key ultrasound features., ${ }^{9,13,14}$

Monochorionic monoamniotic twins should raise the suspicion of conjoined twins and detailed sonographical assessment should be done to detect any shared vital organs for optimal management of pregnancy and birth. ${ }^{4}$ Termination of preganancy is advised if dicephalic twins are detected especially if additional lethal congenital malformations are also present.

Termination of pregnancy is also advised for antenatal diagnosis of sirenomelia. Hence antenatal diagnosis of sirenomelia in dicephalic parapagus twins discordant for anencephaly and spina bifida leaves with no option other than terminating the pregnancy.

\section{CONCLUSIONS}

Sirenomelia in dicephalic parapagus dibrachius conjoined twins discordant for anencephaly and spina bifida is a rare anomaly and highly lethal.

\section{REFERENCES}

1. Yang PY, Wu CH, Yeh GP, Hsieh CT. Prenatal diagnosis of parapagus diprosopus dibrachius dipus twins with spina bifida in the first trimester using two- and three-dimensional ultrasound. Taiwan J Obstet Gynecol. 2015;54(6):780-3.

2. Swar MO, Khawaga MA, Altahir SH. Dicephalus tribrachius conjoined twins: Case report and review of literature. Sudan J Paed. 2011;11(2):50-3

3. Usang UE, Olasode BJ, Archibong AE, Udo JJ, Eduwem DA. Dicephalus parapagus conjoined twins discordant for anencephaly: a case report. J Med Case Reports. 2010;4:38.

4. Kaveh M, Kamrani K, Naseri M, Danaeian M, Asadi F, Davari-Tanha F. Dicephalic parapagus tribrachius conjoined twins in a triplet pregnancy: a case report. J Fam Reproduct Health. 2014;8(2):83-6.

5. Watanabe K, Ono M, Shirahashi M, Ikeda T, Yakubo K Dicephalus Parapagus Conjoined Twins Diagnosed by First-Trimester Ultrasound. Case Reports Obstet Gynecol 2016;2016:8565193.

6. Kuraishy A, Noor N, Kuraishy I. Dicephalic Parapagus Twins: A Rare Case Report. Int J Obstet Gynaecol. 2017;4(1):542-8.

7. Karaer A, Tanrikulu I, Gunes N, Cakir E, Oztas A. Parapagus dicephalus dibrachus dipus: A case of conjoined twins. J Turkish German Gynecol Assoc. 2009;10(4):241-3.
8. Duhamel B. From the Mermaid to Anal Imperforation: The Syndrome of Caudal Regression. Arch Dis Child. 1961;36(186):152-5

9. Valenzano M, Paoletti R, Rossi A, Farinini D, Garlaschi G, Fulcheri E. Sirenomelia. Pathological features, antenatal ultrasonographic clues, and a review of current embryogenic theories. Human Reproduct Update. 1999;5(1):82-6.

10. Hernandez JCM, Uribe MAM, Perez JAD, Gracia E. Sirenomelia in siamese twins. First case report of the literature. Virchows Arch. 2008(1):S1-S286.

11. Harma M, Harma M, Mil Z, Oksuzler C. Vaginal delivery of dicephalic parapagus conjoined twins: case report and literature review. Tohoku J Experiment Med. 2005;205(2):179-85.

12. Kumru P, Demirci O, Kahraman ST, Tugrul S, Arısoy R, Ertekin A. Diagnosis of male dicephalus parapagus dibrachius conjoined twins discordant for anencephaly at early weeks of pregnancy. Case report. Ginecoeu. 2014;10:38-9.

13. Nisenblat V, Leibovitz Z, Paz B, Shapiro I, Degani S, Ohel G. Dizygotic twin pregnancy discordant for sirenomelia. J Ultrasound Med. 2007;26(1):97-103.

14. Van Zalen-Sprock MM, van Vugt JM, van der Harten JJ, van Geijn HP. Early second-trimester diagnosis of sirenomelia. Prenatal Diagnosis. 1995;15(2):171-7. 